\title{
FAKTOR-FAKTOR PENYEBAB DAN DAMPAK RENDAHNYA MINAT BACA BUKU TARUNA POLITEKNIK ILMU PELAYARAN MAKASSAR
}

\author{
Novianty Palayukan \\ Politeknik Ilmu Pelayaran Makassar \\ Jalan Tentara Pelajar No. 173 Makassar, Kode pos. \\ 90172 Telp. (0411) 3616975; Fax (0411) 3628732 \\ E-mail: pipmks@pipmakassar.com
}

\begin{abstract}
The writing titled "Faktor-Faktor Penyebab dan Dampak Rendahnya Minat Baca Buku Taruna Politeknik IImu Pelayaran" describes about the low of reading interest on students at Makassar Merchant Marine Polytechnic. This writing aims to identify the factors cause the low of reading interest and their impacts on students at Merchant Marine Polytechnic. The writer does this research in Makassar Merchant Marine Polytechnic during August. In this writing, the writer uses descriptive method and qualitative approach in collecting data by observation, interview and library research. The data which are collected in the means of observation and information result from various sources of both litertures and informen are analyzed by qualitative analysis method. The result of this research shows some factors identified which cause the low of reading interest on students at Makassar Merchant Marine Polytechnic, they are : the usage of electronic media fluently on students, internal motivation from kids, tightly scheduled on campus, and the low of library service. The impacts of these cause the low of achievement in the class/study, some disease caused by electronics radiant, the lack of self confidence, creativity, and the capability of communication and socialization.
\end{abstract}

Keywords : Reading interest, students, electronic media

\section{PENDAHULUAN}

Di era modern yang semakin maju, masyarakat Indonesia dituntut dapat menggunakan semua fasilitas yang serba canggih dan modern. Karena itulah, tingkat komsumtivitas terhadap barang-barang elektronik yang modern dan canggih pun semakin tinggi. Sebagai contoh, hadirnya televisi, video game, play station, penggunaan alat telepon selular atau yang dikenal dengan nama handphone dan komputer yang mudah dibawa kemana-mana alias Laptop/notebook sudah dapat ditemukan dimana- 
mana. Pengguna peralatan tersebut pada umumnya remaja yang masih duduk di bangku sekolah, mahasiswa, pegawai, bahkan anak-anak Sekolah Dasar. Yang menarik di sini adalah, peningkatan pengguna peralatan tersebut seiring dengan menurunnya minat baca masyarakat pada umumnya.

Apabila dibandingkan dengan era-era sebelum tahun 2000-an. Penggunaan alat-alat tersebut masih sangat sedikit bahkan dapat dikatakan langka. Pada saat itu lebih sering ditemukan siswa, atau mahasiswa yang melakukan aktivitas membaca baik itu di angkutan umum ataupun di perpustakaan. Begitu juga anak pada tingkat sekolah dasar dan pegawai lebih senang melakukan aktivitas membaca di waktu-waktu senggang mereka.

Di Politeknik IImu Pelayaran (PIP) Makassar, misalnya, sebagai salah satu Perguruan Tinggi yang mendidik mahasiswa yang lebih dikenal dengan istilah taruna, aktivitas membaca merupakan aktivitas yang paling jarang ditemui bahkan di perpustakaan. Umumnya taruna ke perpustakaan apabila hendak mengerjakan tugas yang diberikan dosen, atau karena dosen mata kuliah tidak hadir sehingga mereka tidak memiliki kegiatan, atau karena ingin meminjam buku.

Berdasarkan data yang berasal dari perpustakaan PIP Makassar, sejak tahun 2015 sampai dengan sekarang pengguna perpustakaan hanya berkisar antara 15-20 taruna setiap harinya. Ini menunjukkan bahwa tidak terjadi peningkatan jumlah pengguna perpustakaan sejak tahun 2015. Padahal jumlah taruna setiap tahun meningkat. Dibandingkan dengan jumlah pengguna perpustakaan sebelum tahun 2015 lebih banyak daripada jumlah pengguna perpustakaan saat ini. Dari hasil pengamatan penulis, pengguna perpustakaan didominasi oleh taruna semester I sampai dengan semester IV, sedangkan taruna semester VII, VIII dan Perwira Siswa sangat minim menggunakan perpustakaan sebagai tempat membaca. 
Begitu pula dengan hasil pengamatan penulis selama bekerja di PIP Makassar, di waktu senggang taruna lebih sering ditemukan tidur di kelas, bergosip, atau bahkan menonton film di laptop dibandingkan dengan membaca buku. Sebagai salah seorang dosen mata kuliah, penulis seringkali menemukan taruna seolah tidak pernah belajar sama sekali bahkan saat akan ujian.

Kegiatan tanya jawab di kelas pada saat perkuliahan tidak hidup karena hampir sebahagian besar pertanyaan tidak dapat dijawab oleh taruna. Sama halnya saat penulis memberikan tugas baik berkelompok maupun individu yang membutuhkan referensi dalam penyelesaiannya, hasilnya sangat tidak memuaskan.

Berdasarkan latar belakang yang merupakan hasil pengamatan serta wawancara dengan beberapa taruna, maka dirumuskanlah masalah, yaitu faktor-faktor apa yang menyebabkan rendahnya minat baca buku taruna PIP Makassar serta apa dampaknya.

Tujuan penulisan ini adalah untuk mengetahui faktor-faktor penyebab dan dampak dari rendahnya minat baca buku taruna PIP Makassar dan diharapkan tulisan ini dapat bermanfaat bagi para pembaca, institusi dan khususnya taruna PIP Makassar.

\section{METODE PENELITIAN}

Penelitian ini dilaksanakan di Politeknik Ilmu Pelayaran (PIP) Makassar pada bulan Agustus 2019. Penelitian ini merupakan penelitian deskriptif dengan pendekatan kualitatif. Data penelitian yang digunakan penulis berasal dari hasil studi kepustakaan, pengamatan dan wawancara mengenai hal-hal apa saja yang menjadi penyebab rendahnya minat baca buku taruna PIP Makassar. Selanjutnya data-data berupa hasil pengamatan dan informasi dari berbagai sumber kepustakaan maupun informasi secara lisan dari informan dianalisis dengan menggunakan metode analisis data kualitatif secara umum. 


\section{DASAR TEORI}

\section{Definisi Membaca}

Membaca merupakan salah satu fungsi yang paling penting dalam hidup. Semua proses belajar didasarkan pada kemampuan membaca (Gleen Doman (1991 : 19) dalam bukunya How to Teach Your Baby to Read).

Henry Guntur Tarigan berpendapat bahwa "Membaca adalah suatu proses yang dilakukan serta dipergunakan oleh pembaca untuk memperoleh pesan yang hendak disampaikan oleh penulis melalui media kata-kata atau bahasa tulis" (Membaca Sebagai Suatu Keterampilan Bahasa ).

Suatu proses yang menuntut agar kelompok kata yang merupakan suatu kesatuan akan terlihat dalam pandangan sekilas, dan agar makna katakata secara individual akan dapat diketahui. Kalau hal ini tidak terpenuhi, maka pesan yang tersurat dan yang tersirat tidak akan tertangkap atau dipahami, dan proses membaca itu tidak terlaksana dengan baik.

Membaca dapat pula dianggap sebagai suatu proses untuk memahami yang tersirat dalam yang tersurat, yakni memahami makna yang terkandung di dalam kata-kata yang tertulis. Makna bacaan tidak terletak pada halaman tertulis tetapi berada pada pikiran pembaca. Demikianlah makna itu akan berubah, karena setiap pembaca memiliki pengalaman yang berbeda-beda yang dipergunakan sebagai alat untuk menginterpretasikan kata-kata tersebut.

Harimurti Kridalaksana mengatakan "Membaca adalah menggali informasi dari teks, baik yang berupa tulisan maupun dari gambar atau diagram maupun dari kombinasi itu semua" (Kamus Linguistik). 
Soedarso juga berpendapat bahwa "Membaca adalah aktivitas yang kompleks dengan mengerahkan sejumlah besar tindakan yang terpisahpisah, meliputi orang harus menggunakan pengertian dan khayalan, mengamati, dan mengingat-ingat"(Sistem Membaca Cepat dan efektif).

Sedangkan DP. Tampubolon berpendapat bahwa "Membaca adalah kegiatan fisik dan mental yang dapat berkembang menjadi suatu kebiasaan"( Kemampuan Membaca Tehnik Membaca Efektif dan Efisien ).

Bahkan ada pula beberapa penulis yang beranggapan bahwa membaca adalah suatu kemauan untuk melihat lambang-lambang tertulis serta mengubah lambang-lambang tertulis tersebut melalui suatu metode pengajaran membaca seperti fonik (ucapan, ejaan berdasarkan interpretasi fonetik terhadap ejaan biasa) menjadi membaca lisan.

\section{Macam-Macam Membaca}

\section{Macam-Macam Membaca secara Visual}

Membaca secara visual dapat dibedakan menjadi 2, yaitu : membaca nyaring dan membaca dalam hati

\section{a. Membaca nyaring}

Membaca nyaring adalah suatu kegiatan baca yang ditandai dengan keluarnya bunyi bacaan secara lengkap, dengan menggunakan intonasi baca yang baik, agar isi bacaan tersebut dapat didengar, dimengerti, dan dipahami. baik oleh si pembaca maupun oleh si pendengar (penyimak). Jadi jelaslah bahwa membaca nyaring merupakan kegiatan pembaca bersama-sama dengan orang lain dalam menangkap makna sebuah bacaan (tulisan).

Pembaca nyaring yang baik haruslah memiliki sifat-sifat sebagai berikut: 
- Terampil menafsirkan lambang-lambang yang tertulis, sehingga cfapat menghidupkan makna dari tulisan yang dibacakannnya;

- Mempunyai kemampuan yang tinggi dalam mengerti dan memahami makna serta perasaan yang terkandung dalam tulisan yang dibacanya;

- Memiliki kecepatan pandang yang tinggi serta arah pandangan yang luas, karena dia harus melihat pada bahan bacaan dan memelihara kontak mata dengan orang lain yang bertindak sebagai si pendengar (penyimak);

- Mampu mengelompokkan kata-kata dengan baik dan tepat, supaya jelas maknanya bagi si pendengar (penyimak).

b. Membaca dalam hati

Membaca dalam hati adalah suatu kegiatan baca yang ditandai dengan tidak terdengarnya bunyi atau ujaran dari si pembaca. Membaca dalam hati merupakan suatu keterampilan membaca yang sebenarnya, yang meliputi keterampilan komunikasi tulisan, keterampilan mengubah wujud tulisan menjadi wujud makna, keterampilan menangkap pokok-pokok pikiran dari bahan bacaan dan keterampilan mengerti serta memahami segala yang tersirat dalam bahan bacaan.

Dengan kata lain, membaca dalam hati lebih ditujukan untuk menggali, mengerti, dan memahami makna atau arti, baik yang tersurat maupun yang tersirat dalam bacaan tersebut. Membaca dalam hati merupakan suatu keterampilan membaca yang sebenarnya, yang meliputi keterampilan komunikasi tulisan, keterampilan mengubah wujud tulisan menjadi wujud makna, keterampilan menangkap pokok-pokok pikiran dari bahan bacaan dan keterampilan mengerti serta memahami segala yang tersirat dalam bahan bacaan. 


\section{Membaca dilihat dari tujuan membaca}

Ditinjau dari segi tujuan akhir dalam aktivitas membaca, membaca dapat dibedakan atas tiga kelompok, yaitu: membaca pemahaman, membaca kritis, dan membaca ide.

a. Membaca Pemahaman

Membaca pemahaman adalah membaca bahan bacaan dengan menangkap pokok-pokok pikiran yang lebih tajam dan dalam, sehingga terasa ada kepuasan tersendiri setelah bahan bacaan itu selesai dibaca. Tujuan akhir dari membaca pemahaman ini adalah terciptanya suatu pengertian dan pemahaman pada diri pembicara tentang segala sesuatu (informasi), baik yang tersurat maupun yang tersirat dalam bacaan tersebut.

b. Membaca Kritis

Membaca kritis adalah suatu kegiatan membaca yang tidak terbatas hanya untuk mengerti dan memahami apa yang dikemukakan oleh penulis, melainkan sampai kepada pertanyaan mengapa hal itu dikemukakan, bagaimana hal itu bisa terjadi, serta akibat apa yang dapat ditimbulkannya. Jadi, membaca kritis merupakan kegiatan membaca yang dilakukan secara bijaksana, penuh tenggang rasa, mendalam, evaluatif, dan analitis.

c. Membaca Ide

Membaca ide merupakan jenis kegiatan mera-aca yang bertujuan mencari, memperoleh, serta memanfaatkan ide-ide yang terdapat pada bacaan. Pembaca ide akan dapat mencari, menemukan, serta mendapatkan keuntungan dari ide-ide yang terkandung dalam 
bahan bacaan, jika ia mampu dan benar-benar terampil menangkap ide-ide yang terkandung di dalam bahan bacaan tersebut.

\section{HASIL DAN PEMBAHASAN}

Sebelum penulis memaparkan apa saja faktor yang menyebabkan rendahnya minat baca taruna PIP Makassar, ada baiknya penulis paparkan terlebih dahulu manfaat membaca. Berdasarkan hasil studi kepustakaan, penulis menyimpulkan beberapa manfaat membaca, yaitu antara lain sebagai berikut:

1. Membaca dapat menghilangkan kecemasan dan kegundahan

2. Ketika sibuk membaca, seseorang terhalang masuk ke dalam kebodohan

3. Kebiasaan membaca membuat orang terlalu sibuk untuk bisa berhubungan dengan orang-orang malas dan tidak mau bekerja

4. Dengan sering membaca, orang bisa mengembangkan keluwesan dan kefasihan dalam bertutur kata

5. Membaca membantu mengembangkan pemikiran dan menjernihkan cara berfikir

6. Membaca meningkatkan pengetahuan seseorang dan meningkatkan memori serta pemahaman

7. Dengan membaca, orang mengambil manfaat dari pengalaman orang lain; kearifan orang bijak dan pemahaman para sarjana

8. Dengan sering membaca, orang mengembangkan kemampuannya baik untuk mendapat dan memproses ilmu pengetahuan maupun untuk mempelajari berbagai disiplin ilmu dan aplikasinya dalam hidup

9. Membaca membantu seseorang untuk menyegarkan pemikirannya dari keruwetan dan menyelamatkan waktunya agar tidak sia-sia

10. Dengan sering membaca, orang bisa menguasi banyak kata dan mempelajari berbagai tipe dan model kalimat; lebih lanjut lagi, seseorang bisa meningkatkan kemampuannya untuk menyerap 
konsep dan untuk memahami apa yang tertulis 'di antara baris demi bris' (memahami apa yang tersirat).

Dari berbagai sumber informasi yang diperoleh penulis, rendahnya minat baca taruna umumnya diakibatkan oleh dampak dari perkembangan teknologi, seperti penggunaan media elektronik canggih yang sebahagian besar dimiliki dan atau dipergunakan oleh taruna. Perkembangan teknologi sebenarnya berdampak sangat positif bagi masyarakat, seperti penggunaan media elektronik handphone dan laptop yang sangat memudahkan taruna dalam berkomunikasi dan mengerjakan tugas-tugas mereka. Akan tetapi penggunaan media tersebut lebih sering dimanfaatkan untuk hal-hal yang hanya bersifat menghibur. Contohnya penggunaan handphone yang sekedar untuk chatting (mengobrol) dengan teman. Begitu pula dengan hadirnya fasilitas internet yang memudahkan para penggunanya dalam mengakses data maupun informasi lebih sering dimanfaatkan oleh taruna untuk menjadi media penghibur dan sarana untuk bergaul.

Keinginan masyarakat pada umumnya yang menyukai segala sesuatu yang serba instan juga ikut menjadi penyebab rendahnya minat baca buku. Di kalangan remaja, mahasiswa bahkan pegawai, pengunaan segala sesuatu yang instan atau serba cepat selalu menjadi pilihan utama. Hal inilah yang juga terjadi pada taruna PIP Makassar. Saat fasilitas internet mulai ada, sebahagian besar taruna memanfaatkan untuk mencari referensi apakah dalam rangka menyelesaikan tugas harian ataupun tugas akhir. Hampir tidak ada yang tidak menggunakan fasilitas internet untuk mengerjakan berbagai tugas perkuliahan mereka. Sangat wajar dan dimengerti apabila taruna bahkan sebahagian besar mahasiswa menggunakan internet untuk mengakses informasi dan referensi yang dibutuhkan karena prosesnya sangat cepat dan tidak membosankan. Saat mencari referensi dengan membaca buku, bagi para pengguna internet sudah pasti dinilai sangat membosankan sehingga minat baca buku dengan sendirinya akan menurun bahkan hilang. 
Di samping itu, dengan hadirnya fasilitas jejaring sosial seperti friendster, facebook, twitter, myspace dan lain sebagainya mendukung semakin rendahnya minat baca taruna. Meski tujuan utama penggunaan internet untuk mencari tahu berbagai informasi yang penting bagi pengetahuan mereka, namun secara tidak sadar seringkali, bahkan hampir selalu penggunaan internet dilakukan untuk mencari informasi sekaligus berbagi status dan komentar melalui situs-situs jejaring sosial tersebut. Bahkan beberapa kali penulis mendapati taruna yang mengisi waktu senggang mereka dengan men-download berbagai games dan filmfilm yang tentunya hanya bersifat menghibur.

Beberapa kali penulis menanyakan kepada taruna dari berbagai tingkatan sehubungan dengan kegiatan mereka di waktu luang. Karena padatnya jadwal kegiatan baik akademik maupun kegiatan ketarunaan, hampir tidak tersisa waktu luang bagi para taruna.keseluruhan, waktu luang bagi taruna PIP Makassar biasanya ada pada saat tidak ada perkuliahan, dalam hal ini, tidak ada jadwal perkuliahan atau dosen yang seharusnya melaksanakan perkuliahan tidak hadir atau berhalangan. Waktu luang yang lain tersedia di malam hari setelah kegiatan ibadah malam selesai dan sebelum apel malam hari. Sebahagian besar taruna yang masih berada pada tingkat I (semester I dan II) menggunakan waktu luang mereka dengan membaca, mengerjakan tugas, atau tidur. Alasan mereka membaca bukanlah karena mereka hobi membaca, tetapi lebih kepada mencari cara untuk mengisi waktu luang mereka dengan melakukan hal yang setidaknya bisa menguntungkan atau bermanfaat bagi mereka. Setelah diamati dan diwawancarai, pada umumnya mereka membaca di perpustakaan selain karena alasan sebelumnya, juga karena mereka tidak ingin terlihat tidak beraktifitas oleh senior-senior mereka yang berada pada tingkat yang lebih tinggi. Taruna yang terlihat tidak memiliki kesibukan seringkali dinilai malas dan akhirnya mendapat tugas atau bahkan hukuman dari senior mereka. Karena hal inilah, perpustakaan seringkali hanya dipadati oleh mereka yang datang untuk 
sekedar membaca surat kabar, majalah, atau buku-buku lain yang bersifat menghibur.

Berdasarkan informasi dari informan (taruna dan alumni), rendahnya minat baca buku mereka juga disebabkan oleh tidak tertanamnya hobi membaca sejak kecil. Hal ini bisa diakibatkan oleh kurangnya dukungan dari keluarga untuk dapat lebih maju, terdidik, pintar dan cerdas atau bahkan tidak adanya kemauan dan tekad dari individu yang bersangkutan untuk menjadi pintar, maju, terdidik dan cerdas. Ada pula informan yang mengaku bahwa kehidupan yang serba pas-pas-an atau tidak berkecukupan juga mendukung kurangnya minat baca mereka karena harga buku yang tidak terjangkau atau tidak menjadi prioritas dalam kehidupan.

Selain itu, beberapa informan menyatakan bahwa, rendahnya minat baca taruna PIP Makassar juga disebabkan oleh minimnya referensi yang mereka butuhkan khususnya yang menyangkut keahlian dan profesi mereka sebagai calon perwira pelayaran. Taruna, khususnya yang berada pada tingkat akhir (semester VII - VIII) seringkali mengeluh karena kekurangan referensi dalam penyusunan tugas akhir mereka dan waktu penggunaan perpustakaan juga sangat terbatas, yaitu mulai pukul 8.00 16.00 , padahal taruna tinggal di asrama dan juga memiliki kesempatan untuk menggunakan fasilitas perpustakaan di malam hari.

Perpustakaan PIP Makassar sebenarnya telah berupaya mengadakan berbagai macam buku dan referensi baik yang bersifat umum mupun yang sesuai dengan kebutuhan para perwira pelayaran, hanya saja seringkali taruna merasa sulit menemukan buku yang hendak mereka baca. Dari hasil pengamatan penulis, hal ini terjadi karena taruna tidak mengetahui cara penggunaan katalog yang disediakan baik dalam bentuk komputer maupun manual, sehingga mereka menjadi malas dan tidak jadi membaca, hanya membaca apa yang kebetulan ditemukan. Tetapi keadaan ini sebenarnya dapat diantisipasi dengan memberdayakan staf perpustakaan agar selalu siap sedia membantu taruna menemukan 
buku dengan kata lain ikut mendukung aktivitas membaca taruna di dalam perpustakaan. Sejauh ini penulis mengamati bahwa taruna ataupun pengguna perpustakaan yang lain seringkali kesulitan mencari buku yang akan dibaca atau dipinjam tanpa bantuan staf perpustakaan.

Rendahnya minat baca buku taruna PIP Makassar sangat berpengaruh terhadap kecerdasan, kemampuan berkomunikasi, keterampilan, bahkan terhadap sikap perilaku mereka. Minimnya kegiatan membaca taruna berdampak pada nilai-nilai tugas, ujian dan keaktifan mereka saat proses perkuliahan berlangsung. Pada umumnya, seseorang yang tidak suka membaca cenderung tidak kreatif, kurang percaya diri, dan kurang bisa bersosialisasi di masyarakat. Siapapun orangnya, tentulah tidak ingin mengalami hal demikian. Seharusnya taruna PIP Makassar juga menghindari terjadinya hal tersebut karena akan berdampak pula saat hendak mencari pekerjaan dan bersaing dengan lulusan-lulusan dari perguruan tinggi yang lain.

Apa jadinya apabila nilai-nilai ujian rendah karena minat baca yang juga rendah? Bagaimana apabila seorang perwira menjadi kurang percaya diri, tidak kreatif, atau bahkan kurang bisa bersosialisasi karena rendahnya minat baca sejak masih berstatus taruna? Dan bagaimana nasib bangsa kita kelak apabila generasi muda saat ini sudah tidak suka membaca? Pastilah kemajuan bangsa kita menjadi terhambat dan tidak mungkin dapat bersaing dengan bangsa atau negara lain.

Membaca buku dengan cara yang tidak tepat dapat berdampak negatif bagi kesehatan, khususnya kesehatan mata. Akan tetapi penggunaan media elektronik yang dimanfaatkan sebagai media untuk membaca akan lebih besar dampak negatifnya bagi kesehatan dalam jangka waktu tertentu karena semua alat elektronik pasti memiliki efek radiasi yang tidak sedikit. Hal ini tentu dapat mengakibatkan gangguan kesehatan seperti sakit kepala, mata berair, gangguan pada telinga dan bahkan saraf ke otak. 
Dampak lain dari rendahnya minat baca adalah kurangnya nilai-nilai hidup yang bisa dipelajari dan dimiliki dalam kehidupan sehari-hari. Taruna PIP Makassar sebagai calon perwira pelayaran niaga yang diharapkan nantinya dapat mengarungi samudera, tidak dapat membentuk karakter dan perilaku yang sempurna karena kurang memiliki nilai-nilai hidup. Seseorang yang gemar membaca akan banyak memperoleh pelajaran dari berbagai bacaan atau kisah hidup orang/tokoh masyarakat. Seseorang yang kaya akan pengalaman hidup orang lain cenderung lebih berhasil mengarungi samudera kehidupannya sekaligus mampu bekerja dengan lebih professional kapan pun dan di manapun mereka berada.

\section{PENUTUP}

\section{Kesimpulan}

'Membaca adalah jendela dunia' itulah budaya yang seharusnya selalu dipakai untuk meningkatkan minat baca masyarakat, tetapi di masa serba modern dan canggih ini, membaca bukan lagi aktivitas yang diminati khususnya di kalangan remaja dan mahasiswa. Hasil pembahasan pada karya ilmiah ini menunjukkan bahwa meningkatnya penggunaan media elektronik seperti televisi, handphone dan komputer/laptop menjadi salah satu faktor yang menyebabkan rendahnya minat baca buku taruna PIP Makassar yang dalam hal ini merupakan obyek penelitian penulis. Faktor penyebab lainnya antara lain karena kurangnya waktu luang taruna setiap harinya; terbatasnya referensi/buku dan layanan yang tersedia di perpustakaan; serta kurangnya motivasi pribadi terhadap minat baca buku yang juga tidak didukung oleh lingkungan dan keluarga sejak kecil.

Rendahnya minat baca buku taruna PIP Makassar akhirnya akan berdampak secara langsung kepada individu yang bersangkutan. Dari sisi kesehatan, pemanfaatan alat elektronik dalam jangka waktu tertentu akan berdampak buruk bagi kesehatan si pengguna. Minat baca yang rendah akan mempengaruhi dan menyebabkan prestasi, nilai ujian, tugas, keaktifan pada saat perkuliahan pun rendah. Sifat kurang percaya diri dan 
sulit bersosialisasi di masyarakat juga merupakan akibat dari rendahnya minat baca buku. Hal ini akhirnya akan berimbas pada sulitnya taruna mencari pekerjaan saat nanti dia lulus dari PIP Makassar. Pada saat bekerja di atas kapal pun kelak merasa tidak nyaman dan akan sering merasa bosan yang pada akhirnya tidak dapat bekerja dengan baik dan professional. Keadaan ini tentu saja akan berdampak bagi kelangsungan hidup bangsa dan negara kita yang seharusnya mampu bersaing dengan bangsa dan negara lain.

\section{Saran/Rekomendasi}

Dari hasil karya ilmiah ini, ada beberapa hal yang menjadi rekomendasi antara lain sebagai berikut :

1. Diharapkan pihak institusi PIP Makassar dapat mengakomodir kebutuhan taruna akan layanan perpustakaan yang mereka butuhkan, sehingga di waktu luang mereka dapat menggunakan fasilitas perpustakaan dengan mudah dan maksimal.

2. Disarankan pula kepada bagian informatika untuk menutup akses situs-situs internet yang tidak penting, tidak mendidik dan hanya bersifat menghibur pada waktu-waktu tertentu dan pada area-area yang umumnya digunakan taruna.

3. Bagi para taruna, disarankan untuk membudayakan membaca sekurang-kurangnya 1 (satu) jam sehari untuk membiasakan diri sekaligus menambah wawasan pribadi.

4. Pada akhirnya penulis berharap akan ada penulis-penulis lain yang dapat meneliti secara mendalam mengenai minat baca taruna PIP Makassar demi peningkatan pengetahuan serta kemajuan bangsa dan negara. 


\section{DAFTAR PUSTAKA}

Tarigan, Henry Guntur. 1979. Membaca Sebagai Suatu Keterampilan Berbahasa. Bandung: Angkasa

Tampubolon, DP. 1986. Kemampuan Membaca Teknik Membaca Efektif dan Efisien. Bandung: Angkasa

Kridalaksana, Harimurti. 1984. Kamus Linguistik. Jakarta: Gramedia

Madjid, Abd. 2008. Pengaruh Televisi Terhadap Minat Baca Anak. http://www.majidbsz.wordpress.com/feed/2008)

Anonim. 2012. Faktor yang Mempengaruhi Rendahnya Minat Baca. http://theladunni.blogspot.com/2012/02

Hari Karyono. 2012. Menumbuhkan Minat Baca Sejak Dini. http://harikaryo.wordpress.com/2012/04/06

Kumpulan Karya Pendidikan dan Budaya. 2009. Manfaat Membaca. http://www.lembursingkur.wordpress.com/2009/05/31

Perpustakaan Daerah Cirebon. 2012. 7 Penyebab Rendahnya Minat Baca. http://perpusda.cirebonkab.go.id

Soedarso. 1989. Sistem Membaca Cepat dan Efektif . Jakarta: PT. Gramedia

Supadilah. 2012. Rendahnya Minat Baca Bangsa http://edukasi.kompasiana.com/2012/03/16 